\title{
MEMORANDUM
}

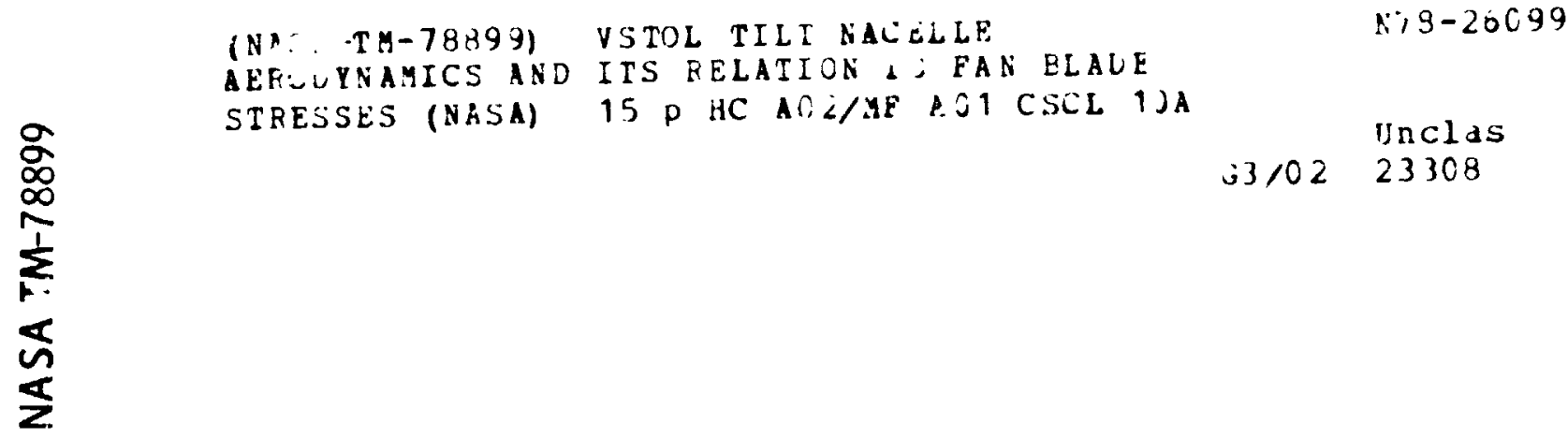

\section{VSTOL TILT NACELLE AERODYNAMICS AND ITS \\ RELATION TO FAN BLADE STRESSES}

by Robert J. Shaw and Robert C. Williams

Lewis Research Center

Cleveland, Ohio 44135

and

Joseph I. Koncsek

Boeing Military Airplane Development

Seattle, Washington 98124

TECHNICAL PAPER to be preseited at the

Fourteenth Joint Propulsion Conference

cosponsored by the American Institute of

Aerunautics and Astronautics and the

Society of Automotive Engineers

Las Vegas, Nevada, July 25-27, 1978 
VSTOL TILT NACELLE AEROCYNAMICS AND ITS RELATION TO FAN BLADE STRESSES

\author{
Robert J. Shaw and Robert C. Will1ams \\ National Aeronaut $1 \mathrm{cs}$ and Space Administration \\ Lew is Research Center \\ Cleveland, Ohio 44135 \\ and Joseph L. Koncsek \\ Boeing Miltary Airplane Development \\ Seattle, Nashington 98124
}

\section{Abstract}

A scale model of a VSTOL tilt nacelle with a 0.508 m single stage fan was tested in the NASA Lew 1 s $9 \times 15$ Low Speed Wind Tunnel to ascertain inlet aerodynamic and fan seromechanfcal performance over the low speed flight envelope. Fan blade stress maxima occurred at discrele rotational speeds corresponding to integral engine order vibrations of tue flrst flatwise bending mode. Increased fan blade stress levels colncided with internal boundary laver separation occurring but became severe only when the separation location. had progressed to the entry lip region of the inlet. The inlet/fan system could operate within the low speed flight envelope without incurring fan blade stress limits alchough boundary layer geparation did occur for certain operating conditions.

\section{Symbole}

ô

fan face annulus area, $0.160 \mathrm{~m}^{2}$ (1.72 $\left.\mathrm{et}^{2}\right)$

inlet hilite area, $0.177 \mathrm{~m}^{2}$ $\left(1.90 \mathrm{ft}^{2}\right)$

Inlet throat area, $0.171 \mathrm{~m}^{2}$ ( $1.84 \mathrm{ft}^{2}$ )

CR

inlet area contraction ratio

d

dietance normal to local inlet vurface

bl

boundary idyer rake height, $0.191 \mathrm{~m}(0.0626 \mathrm{ft})$

$\mathbf{L}$

Inlet axial length, $0.416=$ (1. $36 \mathrm{ft}$ )

n

fan rotactional apeed

$\mathbf{P}_{\mathbf{t}} / \mathbf{P}_{\mathbf{t}}$

local total pressure recovery

$\bar{P}_{t_{2}} / P_{t_{r}}$

$\left(\frac{P_{t}-\therefore x_{\text {in }}}{\bar{P}_{t}}\right)_{2}$

p/Pt.

41

thu

enroet

Rep

$\mathbf{s}$

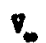

f an face area weighted cotal preasure recovery

fan face area welghted total presesure diecortion

local surface static pressuce ret 10

locel bllite radiue

tan face hub radtus, 0.118 a (0.384 ft)

locel th.ont redius

tan fece tip red1 $1,0.254=$ $(0.833 \mathrm{tc})$

inlet wurface coordinate

fres atren velocity

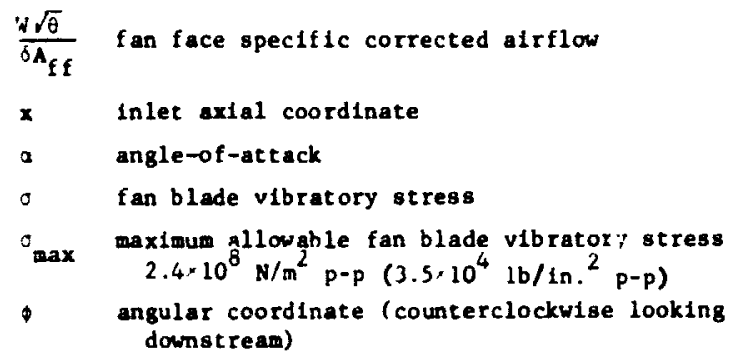

Introduction

A number of potential conflgurations have been advanced as candidates for the Navy Type A VSTOL aizcraft. One such design is the tilt nacelle concept shoun in figure 1 .

Ia the vertical ascent or descent wode, the engine nacelles are rotated to approximately $90^{\circ}$ with respect to the aircraft axis as shown in Fig. $1(a)$. The thrset frow the two t1lt nacelles provide two support posts sor the alrcreft while the third Is provided by the nose fan which is driven by the cilt nacelle powerplanta.

In the cruise mode the nacelles are rotated so as to roughly align with the aircraft axis as show In Fig. I(b). The nose fan is not eaployed in the crulse mode.

The Inlets for the tilt nacelles will experience ingh angles-of-attack at the low foward velocitles characteristic of the take off and landing aneuvers. Representative operating conditions as deternined by alssion studies for such inlets are hown In Fig. 2. It can be seen that tllt nacelle iulets can expertance angles-of-attack a high as $120^{\circ}$ at flight velocity of $21 \mathrm{~m} / \mathrm{sec}$ (40 knots). Such severe operating conditions can revilt in boundary-layer separation within the inlet resultins in Increases in total preseure distortion presented to the powerplant. A mejor concern 10 that the Internal flon separation can result in intolereble levele of fan blade vibratory otrese which could in turn result in fan blede fallure.

A number of experimatal program have been conducted In the pase wich were concerned with the exrodynedic cherecteristice of s70 inlete wha internal flow epparation occur red. $1-6$ sines an inlet for a Vstol application vould in general haw Increased angle-of-altack requiremate, the effecte of Internal flow separation would be expected to be wre envere both on Inlet parfornence ad reoultent fen blede etrees levis.

In order to evaluate the exrodynenteaeromechandeal intorrelationshipe and thus to holp evaluate the viebility of the t11t necelle concept. 
a foint teat program was inttlated between NASA Lew is Researcl. Center and Boelng Military Alrplane Development to test a scale model of a candidate tilt nacelle design with a single stage fan. The intent was to document the inlet aerodynamic and $f$ an aerowechanical performance over the low speed operational envelope of Fig. 2. The overall results of the test program are discussed in Ref.? Thls paper will concentrate on one of the flue design goal points $\left(V_{\infty} \cdot 54 \mathrm{~m} / \mathrm{sec}\right.$ (105 knots), $\left.\perp=75^{\circ}\right)$ and discuss the sallent inlet aerodynamic features and the resultant fan blade vibratory stress signature. Finally the blade stress induced limits on the safe nacelle operating envelope will be discussed.

\section{Apparatus and Procedure}

\section{Test Model}

A schematic of the inlet-fan combination is shown in Fig. 3 .

The inlet was designed by Boeing Military Air plane Developuen: to be a candidate design for a tilt nacelle subsnnic vSTOL aircraft. The inlet is an asymetric design with a local contraction ratio ( $\left(R_{h i} / R_{\text {throat }}\right)^{2}$ ) varying from 1.76 in the windward plane to 1.30 in the leeward plane. The ovelall inlet contraction ratio (A $\left.A_{h l} / A_{t h r o a t}\right)$ is 1.50.

The intent of the design is twofold: (1) to provide a high enough contraction ratio in the windward region to minimize the stat ic pressure gradients imposed on the internal boundary layer and hopefully, Inhibit boundary layer separation and (2) to keep the overall inlet contraction ratio low enough to deliny the drag rise Mach number to a sufficlently high value. A further discussion $c_{i}$ the inlet design philosophy is given in Ref. 8.

The fan 18 angle stage 0.508 diameter design which has a pressure ratio and tip speed representative of the Type A V/STOL alrcraft application. At the nowinal design speed of $8020 \mathrm{rpm}$, the fan pressure ratio $1 \mathrm{~s}$ approxiantely 1.17 and the tip speed is $213.5 \mathrm{~m} / \mathrm{sec}$. At the moximum $f$ an sped of 120 percent of the dealgn value, the $f$ an pressure rat10 181.25 and the tip speed $18256 \mathrm{~m} /$ sec.

The fan has 15 rotor blades and 25 atator blades with a rotor-atator apecing of approxinately one rotor tip chord length. The rotor blades were fabricated from titaniun alloy and heve circular arc atrfoll sections.

The fan has provialons for adjustiag the blade pitch and hance hee no aldapan daspere. All test rune ver conducted ath the blades set st the deign angle.

The fan Is driven by a four-etage turbine powered by high preseure, heated at dellvered to the turbine throuch flow paseages in the nodel support etrut.

The fen norele exte area vas eleed to duplicate a cloibly as posstble the operating line used in a previous full scale inlet-engine tewt in the MAs Ame full ecale wind tunos.

A nore complete discussion of the aercdynantc characturietlce of the fan can be found in bef. 9.

\section{Instrument at ion}

The model instrumentation is shown in Fig. 4 .

The inlet had axtal rows of static pressures locat.:d at three circumferential angles. For this discussion, only the windward plane distributions w11 be presented.

Two removable six tube boundary layer total pressure rakes wire located about midway in the diffuser of the inlet $(x / L=0.63)$ to determine the quality of the diffuser flow. One of the rakes was located $5^{\circ}$ from the windward plane whlle the second was located $50^{\circ}$ from the windward plane.

The quality of the flow entering the $f$ an was determined through the use of $s i x$ equally spaced total pressure rakes each containing 19 total pressure probes. (One rake was located in the windward plane.) S1x of the probes on each rake were positioned to provide an equal area welghted measurement of the fan face flow whlle the remaining tubes were positioned so as to provide a more detalled measurement of the outer surface boundary layer and midchannel flow. The clusest total pressure prote to the outer wall was located 0.6 percent of the duct helght away from the wall.

S1x outer surface static pressure taps were lccated in the fan face plane and located midway between the fan face rakes.

To detect the onset of internal flow separation within the inlet, a miniature dynamic high response total pressure transducer was mounted in the fan f.uce rake plane $2.79 \mathrm{~cm}$ from the outer surface and displaced $7.5^{\circ}$ from the windward plane. The ras output of the transducer was displayed on line during the test.

The fan blade vibratory stresses were measured using three strain gages located at the root of the suction side of the chosen blades at approximately the wid chord position. This position was responsive to all blade vibrational modes and each $b i$ ain goge was calibrated in terms of the maximum stress for each mode. All three gages were monttored riuring the test and indicated esentially identical readIngs. Thus for purposes of this discussion only one of the three strain gage signals was analyzed.

\section{Test Facility}

The test discuseed herein was conducted in the NASA Lewle $9 \times 15$ Low Speed Wind Tunnel which is an atmosheric total presaure facility utth a free at rean velocity range of 0 to $75 \mathrm{~m} / \mathrm{sec}$

A photograph of the model installed in the test section is shown in F18. 5. The model rotetes in a horizontal plane bout a vertical support post which aloo provides paseage for the high pressure turblne drive air. A portion of the adjacent wind tunnel vertical wall was renoved to allow the fan and turbine exhaust fans to pase through the wind tunnel during the high angles of attack.

\section{Teat Procedure}

A enjor concerm during the test wes the eafety of the fan eince it wa anticipated that at the extrese operating conditions, fan blade stresses in excese of lialt value could be encountered. Such 
concern dictated that the following test procedure be eaployed.

Initially a low free stream velocity and angle- of -attack were established with the fan operating dt a low speed ( $1000 \mathrm{rpm})$ which usually corresponded to separated inlet flow. The fan pieed was thus incredsed while the stress levels were continwally monitored until a speed of atout $8000 \mathrm{rpm}$ was reached. If at any time the fan blade stresses reached a limit value, the test sequence was imedlatelv discontinued and the fan speed reduced to a sate condltion. Such a sweep in fan speed wis termed a safety sweep.

Once the safety sweep had established that fan blade stresses were not excesstue, the fan speed wa slowly decreased until the dyiramic pressure transducer showed increased activity which was indicative of boundary layer geparation. A number of steady state data points were then taken to determine the actual onset of separation through the inspection of the windward plane fan face total pressure rake profiles. Additional data points were also taken to document Inlet/fan performance with increasingly severe degrees of separation as well as with an attached boundary layer flow.

At each frec sitrain relocily the angle-of attack was increased in increments of $15^{\circ}$ beginning with $a=0^{\circ}$ and the above described process repeated untll 1 latting values of stress or the desired angle-of-at tack was reached. This process was then repeated for increased freu stream velocitles.

In this manner, the envelope of safe operating conditions was investigated (Flg, 2).

\section{Results and Discussion}

As al ready indicated, one of the five low speed design goal operating points was chosen for analysis and presentation. The results to be shown were typlcal of the overall test results.

Figure 6 presenta the fan blade vibratory stress signature measured for $V_{\infty}=54 \mathrm{~m} / \mathrm{sec}$ (105 knots), a $=75^{\circ}$. Also shown for comparieon is the stress ignature for $V_{\infty} \cdot 54 \mathrm{~m} / \mathrm{sec}(105 \mathrm{knots})$, $a=0^{\circ}$.

Ine flrst, flatwise bending wode atress algneture is shown as a percentage of the maximum allowable stress as function of both inlet apecific corrected alrflow $\left(W r \bar{\theta} / \delta A_{f f}\right)$ and fan rotational sperd (N). The teat results indlcated the only eignificant wode of vibration present was the first flatwice bending wode. The maxteun allowable vibratnry stress as daterulned by a combined analytical/axperiacntal procedure was $2.4 \times 10^{8} \mathrm{~m} / \mathrm{m}^{2}$ peak-to-peak $\left(3.5 \times 10^{4} 1 \mathrm{~b} / \mathrm{in}, 2 \mathrm{p}-\mathrm{p}\right)$.

The etrues ignature can be charactertied as heving two componente: a broudband level superinpowed on which are a serles of diecrete narrow opeed band peaks. These discrete narrow peake correspond to integral numbers of blade vibration cycles per rotational cycle and hence are das 18 nated as the integral ensine order vibration (EO's). That 1s the engine order three (EO3) vibration correspond to three cycles of vibration per rotational cycle.
The integral engine order vitzactons always occur st the same rotat Sunal speeds, but the corresponding inlet alfflow will vary with free stream veloc $1: y$.

The stress signature corresponding to $\alpha=75^{\circ}$ indicates that engine order three through $s i x$ vibrations (EO3 through EO6) were present with the engine order five vibration (EO5) reaching approximately 80 percent of the $11 \mathrm{mit}$ value.

A comparison of the two stress signatures shrwn Indicates the significant effect the inlot arcodynamics have on the resulting vibratory blade stress levels. The signature corresponding to $a=0^{\circ}$ inlet/fan operation can be characterized as a flat broadband proflle with small increases in stress level corresponding to the EO3, EO4, and EOS vibration peaks. The raximum stress level corresponds to the 03 vibration peak and is less than 10 percent of tile maximum allowable stress level. Increasing the angle-of-attack to $75^{\circ}$ and repeating the sequence results in a significantly different stress signature. The broadband stress ievel is no longer flat but shows a large increase in the neighborhood of $4000 \mathrm{rpm}$. The engine order vibration peaks are also increased In level over the corresponding $a=0^{*}$ levels. In wioition the relative levels of the engine order peaks are changed from the $a=0^{\circ} \mathrm{s} 1 \mathrm{~g}$ nature.

In order to understand the cause/effect relatlonship between the inlet aerodynamles and the blade stress signature already shom, the appropriate inlet aerodynamic data $w 1.11$ be presented and discussed.

Figure 7 relates the overall inlet performance in terms of the usual inlet parameters of area welghted total pressure recovery and totai pressure distortion to the stress signature for $a=75^{\circ}$ already shown. The recovery levels were calculated f rom the fan face rake measurements by taking all 19 probes into consideration. Twn distortion calculations are shown - one corresponding to deleting the outer nine percent of the fan face annulus area and the other corresponding to deletiug the outer 26.6 percent of the area. The filled symols indicate that separated flow was ind tcated by the windward plane fan face rake profile.

The figure indicates that the inlet total pressure recovery levels are high regardless of the level of $f$ an blade tress level encountered. The recovery 18 in excess of 99 percent when the boundary layer is attached and drops to only 97 percent for the lowest inlet afrfion for which data were recorded.

It should be polnted out that bountary layer separation to encountered as the fan speed and herce inlet afrflow level are decreased from higher to lower levele (that is, proceeding from $r$ ght to left on this and ubsequent flgures). A alght be expected an the inlet alrflow is reduced and separacion is detected, both of the calculated distortion parameters increase, reach a aximun value and then decrease for further reductions in inlet alrflow, The aximan level of distortion can be seen to occur at approximety the sane Inlet alrflow a does the axime blide etrees level.

The 91 percent area diatortion faramet has weh higher attachad flow distortion levels than does the 73.4 percent oree paraceter. This cen be 
atcrlbuted to the fact that the 91 perceit area parameter uses total pressure measurements thich are vithin the attached boundary layer for l. distortion level calculation. The high lavels $c$. attached flow distortion tend to mask the effect of the total pressure distortion on the blade stress ignature as shown in Fig. 7. That 1s the distortoo levels are relat ively high for low stress unditions and do not increase appreclably for those conditlons for which the blade stress dues increase ignificantly. Ihis fact was noted for all the teat date analyzed.

Such an occurrence prompted the introduction of the 73.4 percent area distortion paraneter whlch vas defined to consider only those measured total presures wich are outside the atcached flow boundary layer. As Fig. 7 indicates, the variation of the 73.6 percent area distortion parameter does tend to agree more with the blade stress algnature ir a qualitative fashion.

Figure 7 also Indicates that algnificant reduction in inlet alrflow could be effected once separation is IIrst observed prior to reaching the anximus vibratory stress level. This result was also observed throughout the test program.

The combination of high total pressure recovery and high distortion implies that that amall region of locally low recovery exist at the fan face. This will be lllustrated in the following figure.

Mgure 8 relates the inlet cerodynanlc characteriotics to the fan blade vibratory stresa characcerlatica for aeries of inlet alrflows. For each artiow, the figure show the tress signature already discussed, the fan face total pressure contour wap. the approprlate individual fan face rake proflles. and the two mid-diffuser boundary layer rake proflles. Figure 9 presents the windward surface static pressure distributions for the same alrflowe.

For the high inlet alrflov $\left(168 \mathrm{~kg} / \mathrm{sec} \mathrm{a}^{2}\right.$, $34 \mathrm{Ib} /$ sec- $f \mathrm{t}^{2}$ ) shown in Fig. B(a), the stress lavel la low (-5 percent) and the contour map ind 1cates an anymeric boundary layer chicknese distribution, act aubstantiated by the windward and leward in lace rake proflles thown wich both show atteched flow profiles. Likewive the two alddiffuser proflles ladicate in attached boundary layer Ilow al though som proflle distortion is moted for the $5^{\circ}$ rake. It should be noted that the redlal position eceles for the boundary layer and fan tace rake profiles are the sam which ala a direct comparieon of the profiles to be code.

It 1o Interesting to note that wile the etrees level correepondting to an inlet atrflow of $168 \mathrm{~kg} / \mathrm{sec}-\mathrm{m}^{2}$ ( $\left.34 \mathrm{dba} / \mathrm{eac}-\mathrm{ft}^{2}\right)$ is $\mathrm{low}$, an increase in Inlet atrflow to that correponding to the en1a order three (EOJ) vibration reculte in a stble ot reas level ( -30 perceat). The 103 vibretion alk to atenificent even though the inlet boundery layer flow to definitely atcached. It to hypotheeleed that an attached aymatic boundery layer thetrose distribution at the fan face like that chow to Ms. 8(a) Io reaponolble tor the lacressed atrese lewi.

A the talet arflow to reduced to $147 \mathrm{~kg} /$

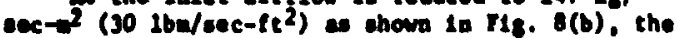

contour adp shows little apparent varbation from that of the higher alrflow already shown. However, the windward plane $\left(* 0^{\circ}\right)$ fan face rake proflle Indicates separated flow exists at the lan face. The fully developed proflle corresponding to the - $60^{\circ}$ rake indicates the separation is a locallzed phenomenon which exists over only a small sector of the fan face $p$ lane. The $5^{\circ}$ ald-diffuser boundary layer rake shows a distorted although still actached protile indtcating cl.e separation location 1. downetream of the asurement plane. The $=50^{\circ}$ rake at1ll Indicates $a$ well developed boundary layer proflle.

For future reference, this condition shown in P18. $8(b)$ wil be termed that condtion correspondIng to the onset of diffuser separation and will be indicated as DS on future stress plots.

If the windward surface static pressure distributions cot cesponding to the two conditions al ready discusged are examined (Fig. 9). Hitle if any indication of the occurrence of boundary laver separation can be detected as the profiles are qualitatively very siallar in nature.

A - light reduction in inlet alrfiow to that level corresponding to the englne order four vibrecion results in olgnificant increase in siress level (-35 percent). Apparently the rather small zono of separated tlow present is suffictent to induce an incresed vibration amplitude. This is especially noticeable when the E04 vibration level (-35 percent) is compared to the EO4 level correaponding to $a=0^{\circ}$ operation ( -5 percent).

It Is Important to note that the location of the inftlal point of boundary layer sepal iton is otable. That is as long as the inlet aivll is kept constant the eparation does not i lipsts ite torward to the entry $11 \mathrm{p}$ region of the initi

Tigure $8(\mathrm{c})$ corresponds to the inlet irslow (119 $\mathrm{kg} / \mathrm{sec}-\mathrm{m}^{2}$. $241 \mathrm{bm} / \mathrm{sec}-\mathrm{ft}^{2}$ ) for wh.ch the fan face dictortion level was the highest ceasurid to the free strean condltions $\left(V_{m}, a\right)$ bein, ducussed. The broadband otreas level increased ignilicanty over that $t c r$ the two hour alrflowe already discussed. The "itour mp hows relatively extenIve spollew sector whlch extends over about 90 destee clrcumferentisl extent.

The I ndvard plane Ian face rake proftle shours - large el aced zone extending over about 30 percent of the duct helght. The cotal pressure levels near the outer (tip) surface are lese then the local outer surface atatic pressute. Inle could be indicative of a reglon of reversed flow exiluting with the cotal preseure probes eseent lally reading a bee preseure level. The occurrence of this supposed tlon reveras appeare to colncide with the maximu etreas levels encountered during che test (for any alven $v, 0$ ).

The fan face profile at $-60^{\circ}$ et1ll show an ateched proflle which indicates the clrcunferent1al extent of the separated sone is leas than $120^{\circ}$ $\left( \pm 60^{\circ}\right)$.

The - $^{\circ}$ ald-dtffuser boundery layer rake profile Indicates the location of ecparation was well forwerd of this etation. The profile for - $50^{\circ}$ Ie attached al though profile distortion I. orident. 


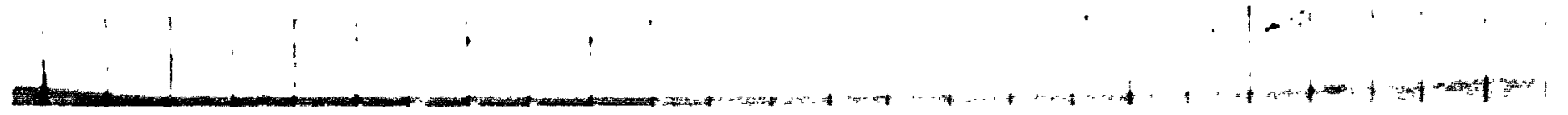

The corresponding windward surface static pressure distribution ( $F 18$. 9) shows a distinct pressure platedu indicative of boundary layer separatlun which searte at approximately the inlet throat station. The difference in character between the pressure proflle and the preceding ones is evident.

1t can be liypothesized that the level of fan blade stress is mainly a function of the discortion level (an intensfty) $d 8$ we 11 as the distortion pattern (an extent). The afgnificant increase in the cos stress level seems to agree with this hypothesis as boch the diatortion intenitty and extent increased when compared to the data shown for the previous inlet airflows.

A further reduction in inlet airflow to $88 \mathrm{~kg} /$ $\sec -\mathrm{m}^{2}\left(181 \mathrm{bm} / \mathrm{sec}^{2} \mathrm{ft}^{2}\right)$ as shown in $\mathrm{Fig}$. $8(\mathrm{~d})$ resulcs in a significant change in the character of the tan tace total pressure contour map. No longer is the cuntour map esientially symetric atout the windward-leeward plane as it is for the previous conditions prestented. The tan tace profiles ind cate the tlow is separated over large portions of the fan face area. These two mid-diffuser boundary layer rake profilen show separated thow also exists at that station.

The stress level for this inlet aitflow is relatively low. Even though the extent of the fan fare distortion is large, the intensity has decreased. This appears to agree with the hypothesis already advanced about blade scress being anction of both the distortion level (intensity) and pattern (extent).

The windward surface static pressure digtribution (Fig. 9) corresponding to this low airflow condition show that the separation location is approximately at the hilite of the inlet. N though nut hwn here, the static pressure distributions corresponding to $\$-45^{\circ}$ and $180^{\circ}$ also indicate separated flow existed from the vicintey of the hilite - at those two clrcumferential positions.

The vibratory utress plot thown in F1g. 8(d) shows an inlet airflow corresponding to separation reaching the vicinity of the inlet entry lip region and designated as LS. This occurrence was deterained by monttoring a undward plane urface stat $1 c$ preseure located approximatily halfway between the inlet hillte and throat locations.

The fan blade vibratory otress level reaches a malmin in broadband level when the eaparation 10cation reachen the vieinicy of the inlet 11p. This correlation between brosdband ot rese waxime and eeparation location held throughout the teat watrix investigated. It should be noted that thile the broadbend strese enxim occur when the eeperation location reaches the vicinity of the inlet $11 \mathrm{p}$, the absolute naxien in etress occur at the fan apeeds corresponding to the integral engine order vibrations.

The fect that the sepdration locetion is etable in thet its locetion can be controlled by the ewount of inlet efrflow deanded by the tan wugeste that two separation boundaries for the inlet are Important. These two boundartes are shown in Fis. 10 o the boundary whth deccribes the Initietion of exparation within the diffueer and a second boundery wich indicates when the separation reaches the vicinity of the inlet lip. It should be noted that the two boundarles shown in Flg. 10 hold only for a free stream velocity of $54 \mathrm{~m} / \mathrm{sec}$ (los knots). Different absolute boundaries would exist for each free stream velocity.

The flgure ind lcates that a elgniflcant reduc$t$ on in inlet dirflo: iall be tolerated once dif fuser separation sccurs prior to the separation location reaching the vicinity of the inlet $11 \mathrm{p}$. It is important to restate that for the test conducted, the separation location was stable and the inlet/ tan combination would be operated indefinitely in the shaded region without any uncoat rolled movement of the separation location occurring.

It Indeed for an actual fllght application, the separation location was again scable, the aperational envelope of the inlec ould be significantly increased by allowing the inlet boundary layer to separate but keeping the separation location from reaching the vicinity of the inlet lip. However. it must be bome in mind that the final determination of the inlet fan operational envelope can only be made when the levels of $f$ an blade vibratory stress encountered are known.

The fan blade vibracory stress signature discussed was generated by reducing the fan speed for a given model angle-of-att i $\mathrm{n}$. Such a procedure allowed the deteruination of the stress levels corresponding to the varlous integral engine order vibrattons as well as any other broadband stress maxIms.

It would be instructive to examine how the stress levela corresponding to the integral engine order vibrations valy with increased angle-ofat tack. However, the extremely narrow widths of the integral engine order vibration peaks made such a determination difficult. For this reason, cross plots of stress level versus angle-of-attack were prepared using the more easily obtainable stress signatures al ready discussed.

Figure 11 shows the variation of the engine order five (EOS) stress level with angle-of-attack for a free stream velocity of $54 \mathrm{~m} / \mathrm{sec}$ (105 knets). A so shown are the appropriate fan face total pressure contoure. It has al ready been show that this etreas peak was the maximue for this free st ream velocity. other ceet data showed that for a majority of tent conditions, this stress peak was the maximun encountered.

The figure indicate that the strese level is inltially low (-2-5 percont) but only increases alightly (-10 percent) when diffuser separation Inttially occura $\left(a-60^{\circ}\right)$. Further increaves in codel angle-of-ateack recult in a continuously lacreasins strese with a level of about 80 percent being reached at 75 degrees. The increasing vibracory atrese levels correspond to the eeparation location noving forward in the inlet toward the entry lip region. This figure also points out the additional inlet angle-of-attack capability avallable if the boundary layer is allmed to eeparate but the separation Incation is kept downstres of the vicinity of the inlet lip.

A elready Indicated the avallable inlet operational envelope cen only be deternined once the $f$ en blade vibratory etress characterietice are know. A noted for a wejority of test conditions, the 
engine order flve (EOS) stices peak was the maximum -tress levil encountered tor glven operating condltlons $\left(V_{\infty}, a\right)$.

With these thoughts in and, the measured EOS etress levels were cumpared to the desited inlet lo epeed de itn goal points and the results are shown in rig. 12. (It ahould be recalled that the lus etreas oecurs at a fixed fan speed which corresponds to an inlet arflow which varles with free utreas veloctty.)

The comparison indicates that the inlet/fan eyaten tested could operaic at the design goal point: wlthout incurring l10iting values of tos stress. However. the stress levels encountered were a high as about 80 percent of the 11 olt value. The figure indicates that the bus stress level was the highest for the uperating poine ( $V_{\text {. }}-54$ atsec. a-75') discussed herein.

Nou hown on the flgure are the two appropriate eerudynamlc separation boundarles which have already been discussed. It can be seen that the onset of diffuser separation would resule in EOS ecreas levels of 40 percent or less. This Indicates that for all free stream velocitles the initial diffueer separat ton would be locallzed and thus would not exclte the EOS vibration to intolerable levels.

The l1p epalation boundary can be seen to roughly agree with a 1 inile libs streys contour (o/ - 100 percent) If one were estlmated from the contours which are shown. This indicaces that regardles: of free stream velosity, the discortion (1.e. Intenalcy and extent) associated with the forward movement of the separation location to the vicinity of the entry lip region excites the gOS vibration to near lint levels.

Several polnts hould be raleed wen this $t$ igure 1s examined. The cerodynablc-aeroelastic corrolation holda only for the fan/inlet combination cested. Other tan deolgas with different aerodyanle propertles, or which have blades fibrleatod froe other miterials (e.e. compondtes) vould be expocted to have elenificartly different vibratory etreas tolerance characteriatica. Also the problem of Inlet cerodynaslc and fan aerumechantcal acaling to expected full ecale perforance are currently not wll underetood.

However the resulte shown herein Indicate the cometiblifty betwen the Inlet enrodynamic and far blede vibratory etrese charecterletics will be of toy coscern in the design of a viable tilt nacelle brol alreraft. It can also be hypothealiod thas other VStOL al reraft dealgne (e.s. . configurations enlo/Ins thruet deflecting nozzles) ay also experIeace efintifcant vibratory otreat levels.

Clearly weh additional work to requitred to Identify the pl per aerodynatic deacriptlve peran-tere in order to quaneify the fan blade vibratory etroes compat lolltity problea.

\section{sunery of Reaules}

A ecale wodel of a tlit necelle lalet designed for the proposed Nav Type A VSTOL alrerate ve cested in the MASA Lowle $9 \times 25$ Low Speod WInd Tunnel. The Inler wa coupled to 0.308 a dianter ingle etene $f_{\text {en }}$ and terted over the expected low opeed llithe envelope. The eajor reoulte can be aup marlzed an follows:

1. Slonificant fan blade vibratory otress levela were encountered which corresponded to integral englne order vibrations. These narrow fan -peed band peaks correaponded to the flrst flatwise bending mode.

2. The highest levels of fan blade stress colncided w th internal boundary layer separation occurring about the windward plane of the inlet.

3. Strese maxima appeared to coincide with the boundary layer separation locat lon reaching the $v 1$ cintey of the entry lip region ot the inlet.

4. The Internal boundary ldver separation inlc1ally occurred well downst ream in the diffuser and the eeparation location was stable. lihat is the eparation location moved forward only ds the inlet airflow demanded by jo fan was decreased. A sigafflcant decrease in inlet alrtlow was necessar; between the intial occurrence of separation in the diffuser and the separation location progressing to the entry lip region of the inlet.

3. Even though inlet eparatior did occur at varlous operating conditions within the low speed 111ght envelope, the inlet/fan systed tested could operate over the envelope without licurring $t$ an blade vibratory atrest levels in excess of the $11 \mathrm{mlt}$ value.

\section{References}

1. Jakubowakl, A. R., and LuIdens, R. W., "Internal Cowl Separation at HIgh Incidence Angles," AIM 75-64, Jan. 1975.

2. Miller, B. A.. Destol1, B. J., and Wesoky, H. L., "Effect of Entry-Lip Design on Aerodynamics and Acoustlcs of High Throst-Mach-Number Inlets for the Quitet. Clean, Shost llaul Experimental EneIne." MASA TH X-3222, 1973.

3. Hiller, B. A.. "Inlats for High Angles of Attack." Journel of Alreraft. Vol. 13, No. 4, Apr. $19 \overline{76 . ~ P P . ~ 319-320 . ~}$

4. LInden R. W., and Abbott. J. M. "Incldence Angle sunds for LIp Flou Separation of Three 13.97 -entineter-Dianeter Inlete." MASA TA $x-$ 3351, 2976.

5. M1ler, B. A. "A Novel Concept for Subsonic Inlet Doundary-Layer Contril." Journal of A1rcreft. Vol. 16, No. 4, Apr. 1977, PP. 403-404.

6. Abbott, J. M. "Aetoceountle Performance of a Scoop Ialet," ALM 77-1354, Oct. 1977.

7. Ronceek, J. L. and shav, R. J., "Operat Ine Charecterintice of an Inlet rodel Teated vith a 0,5 n Powered Tan et Hich Angles-ol-Atcack," boling Co.. Seatele, Wesh., Dis0-2079a-1. Sep. 1977. (NASA CR 135270.)

C. Sybarc, J., and Roneouk, J. L., "Lov Speed Teote of a Fixed Geonery Ialet for e Tile Mecelle v/stol Alrplene," Doetne Co.. Seattle, Wash. D180-20276-1. Jen. 1977, (Musa CR-151922.)

9. Lew1s, G. W., Jr.. and Tyel, L. R., "Overall and liade-Rlecent Performance of a 1.20-Pressure not lo Tan stage at Design Blade Angle setting." msa in $x-3101,80 p .1974$. 


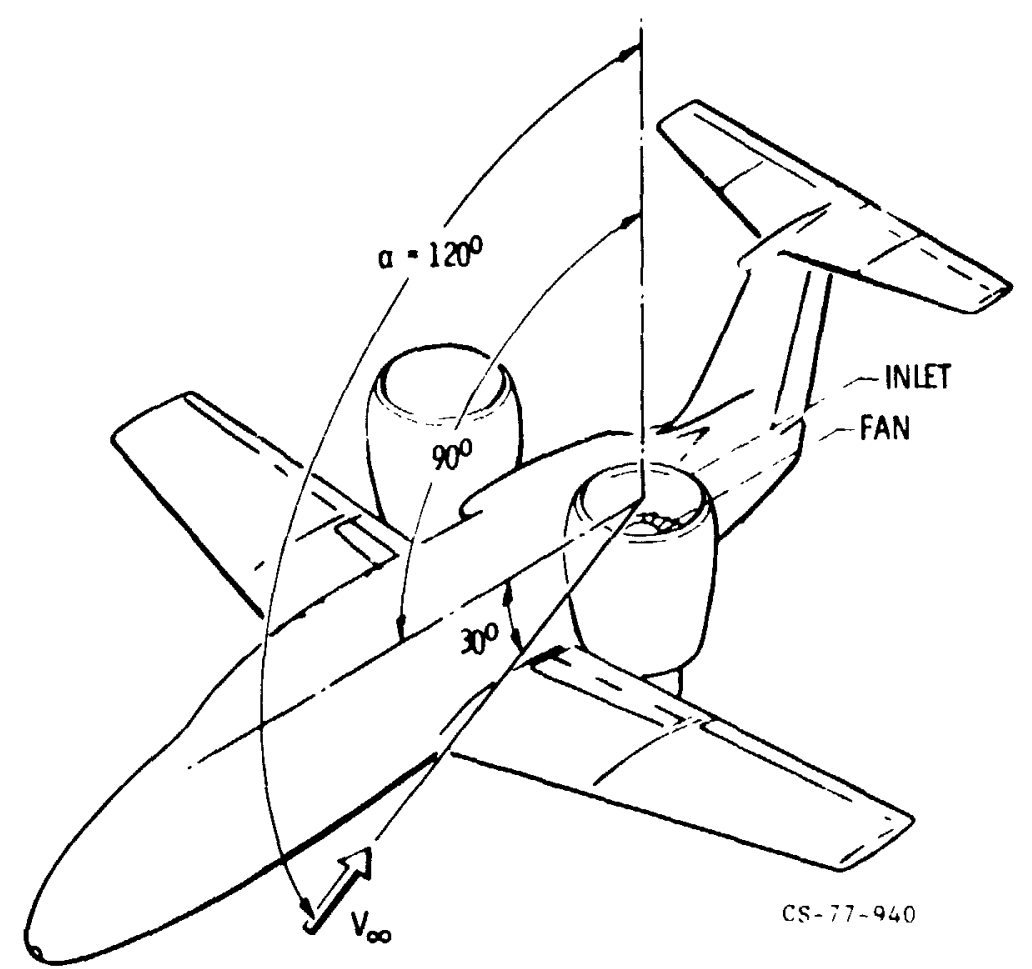

(a) LANDINGTAKEOFF CONFIGURATION.

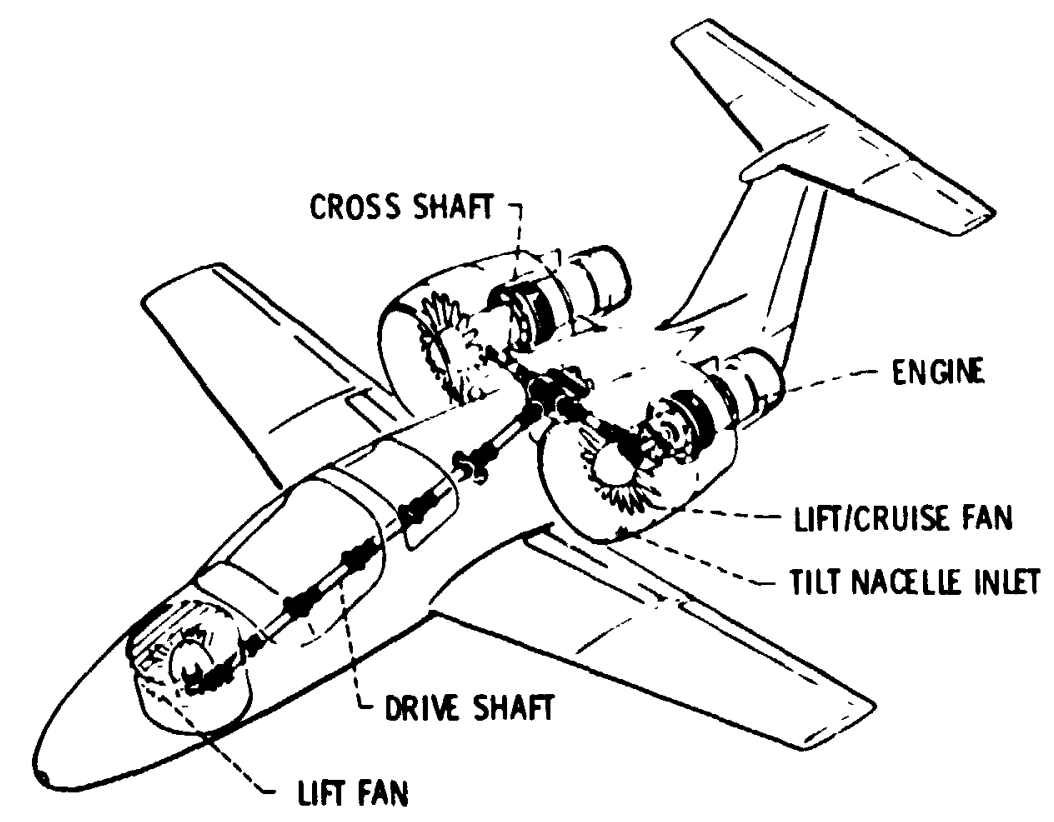

(b) CRUISE CONFIGURATION.

figure 1. - Tilt nacelle VISTOL aircraft. 


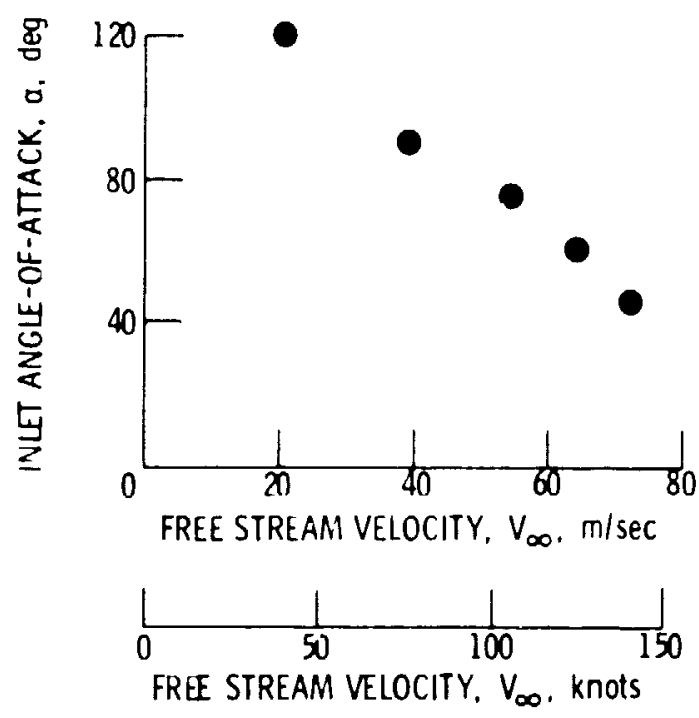

Figure 2. - Tilt nacelle inlet low speed design goals.

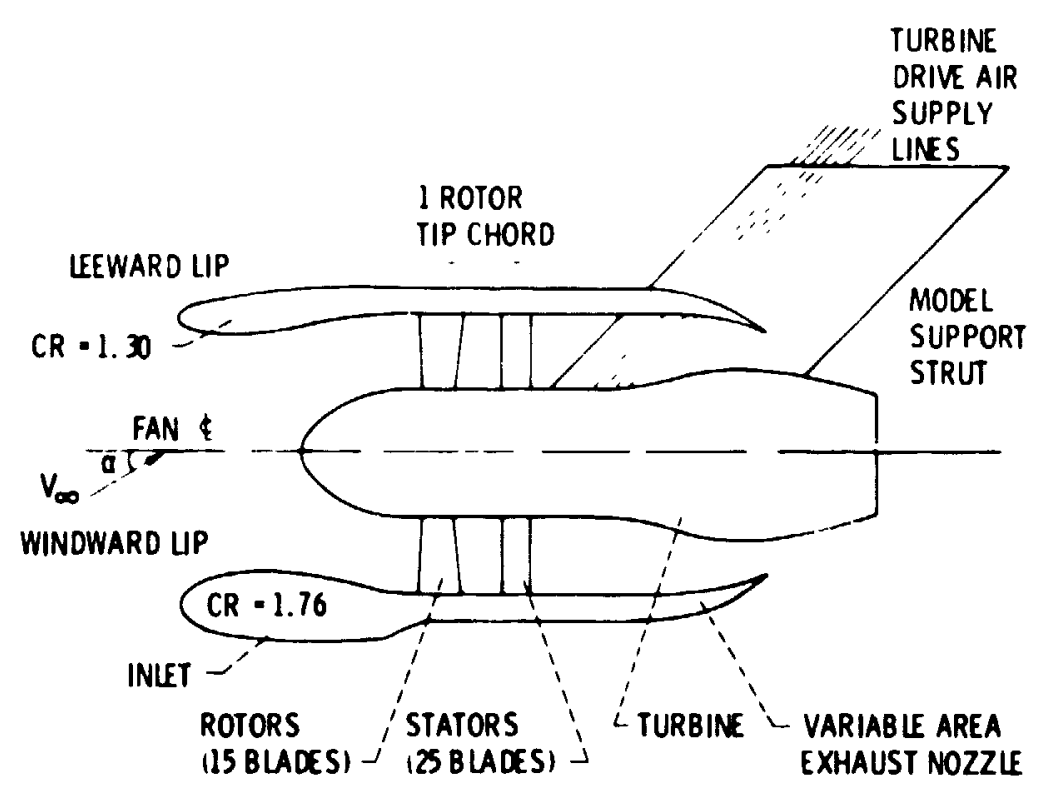

Figure 3. - Inletian assembly. 
$180^{\circ}$ LFEWARD

PLANE

112 STATIC

PRESSURESI

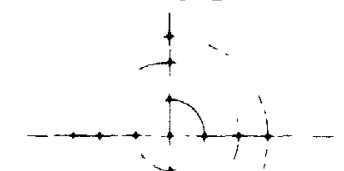

PRESSURE RAKES $(0)$

$|X| L=1.0$

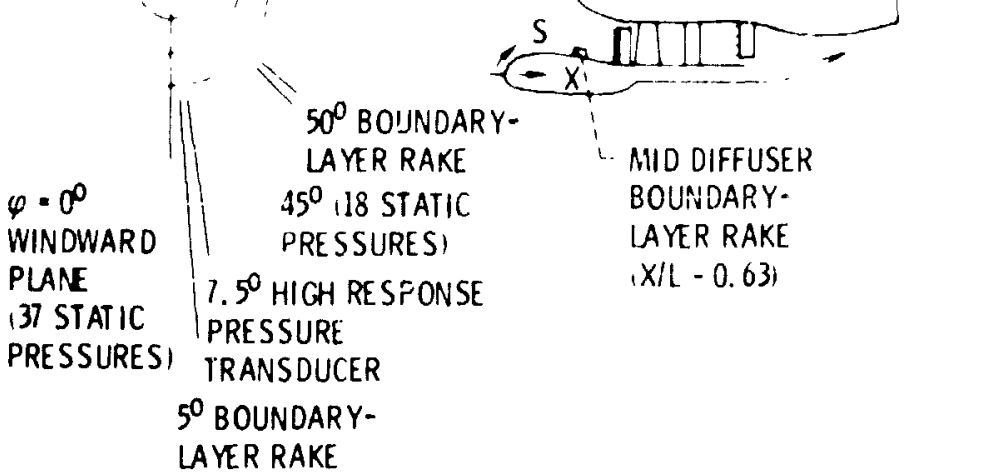

Figure 4. - Instrumentation locátions.

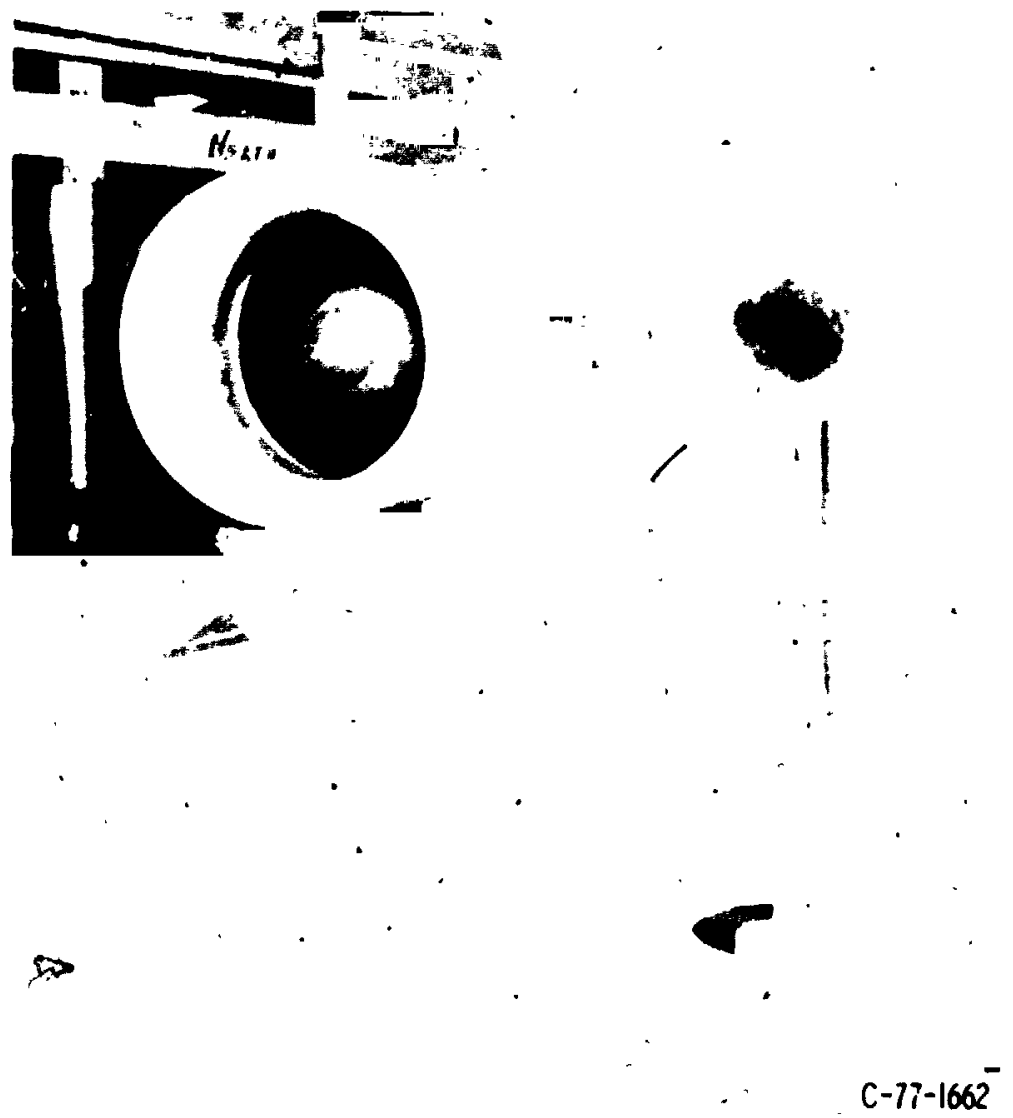

Figure 5. - Tilt nacelle inlet/lan installed in NASA-Lew/s $9 \times 15$ root low speed wind tunnel. 


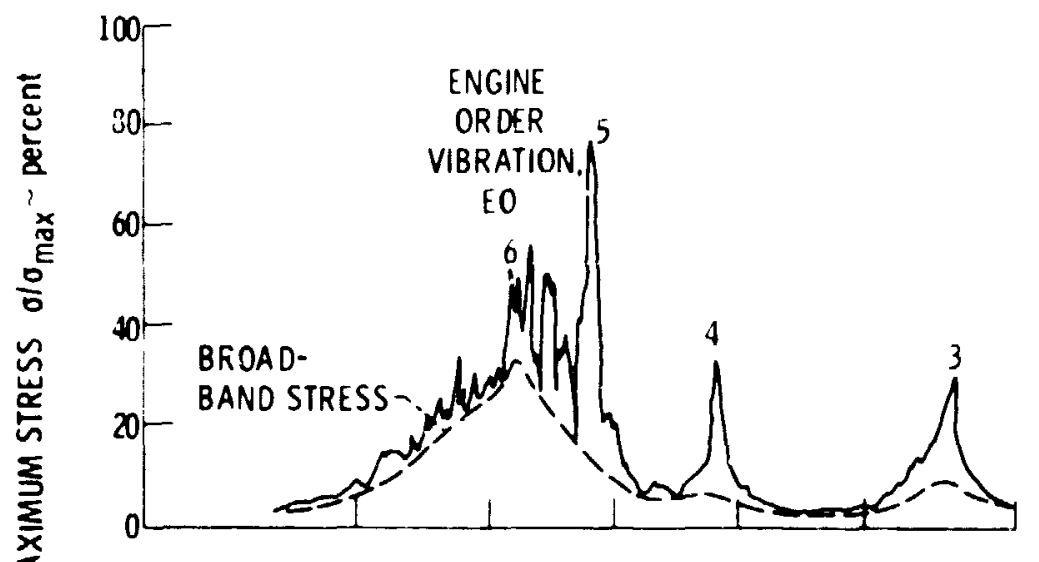

$|a| a=79$.

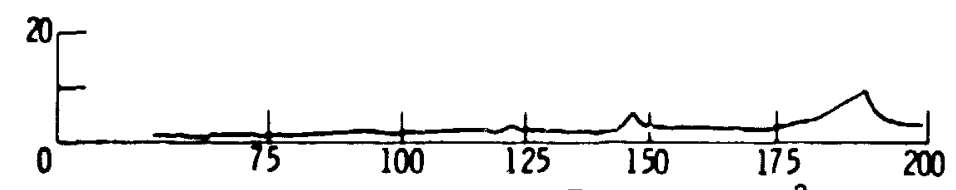

FAN FACE WEIGHT FLOW $W \sqrt{\theta} / \delta A_{f f} . \mathrm{kg} / \mathrm{sec}-\mathrm{m}^{2}$
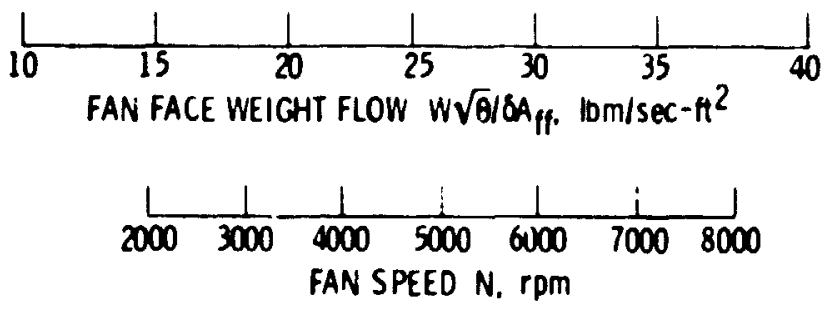

$$
\text { (b) } a=0^{0} \text {. }
$$

Figure 6. - Fan blade vibratory stress characteristics ifirst flatwise bending mode) for $V_{\infty}=54 \mathrm{~m} / \mathrm{sec}(105 \mathrm{knots})$. 

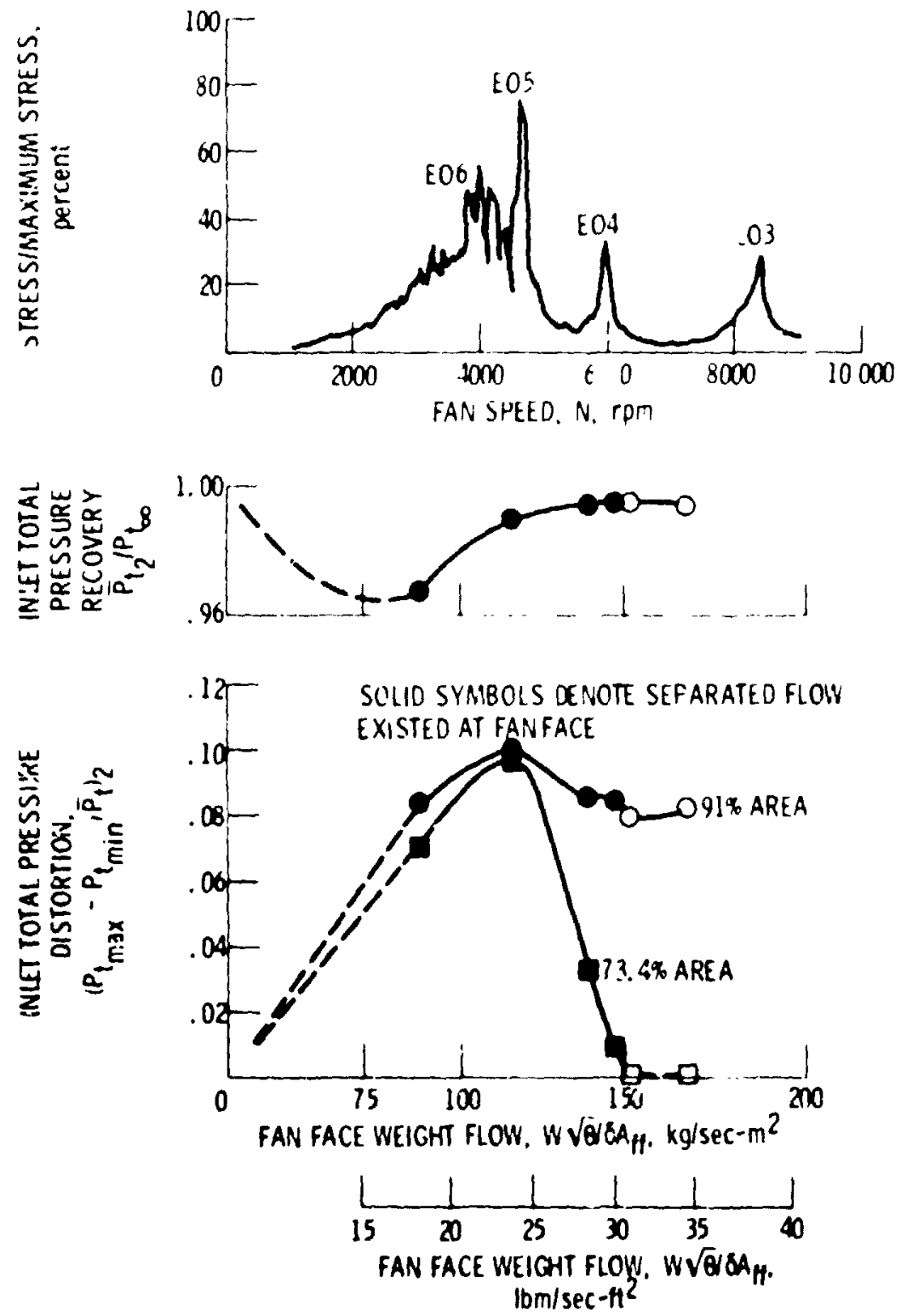

Figure 7. - Inlet aerodynamic performance and fan blade vibratory stress characteristics. $V_{\infty} \cdot 54 \mathrm{~m} / \mathrm{sec} 1105$ knots), $a \cdot 75^{\circ}$. 

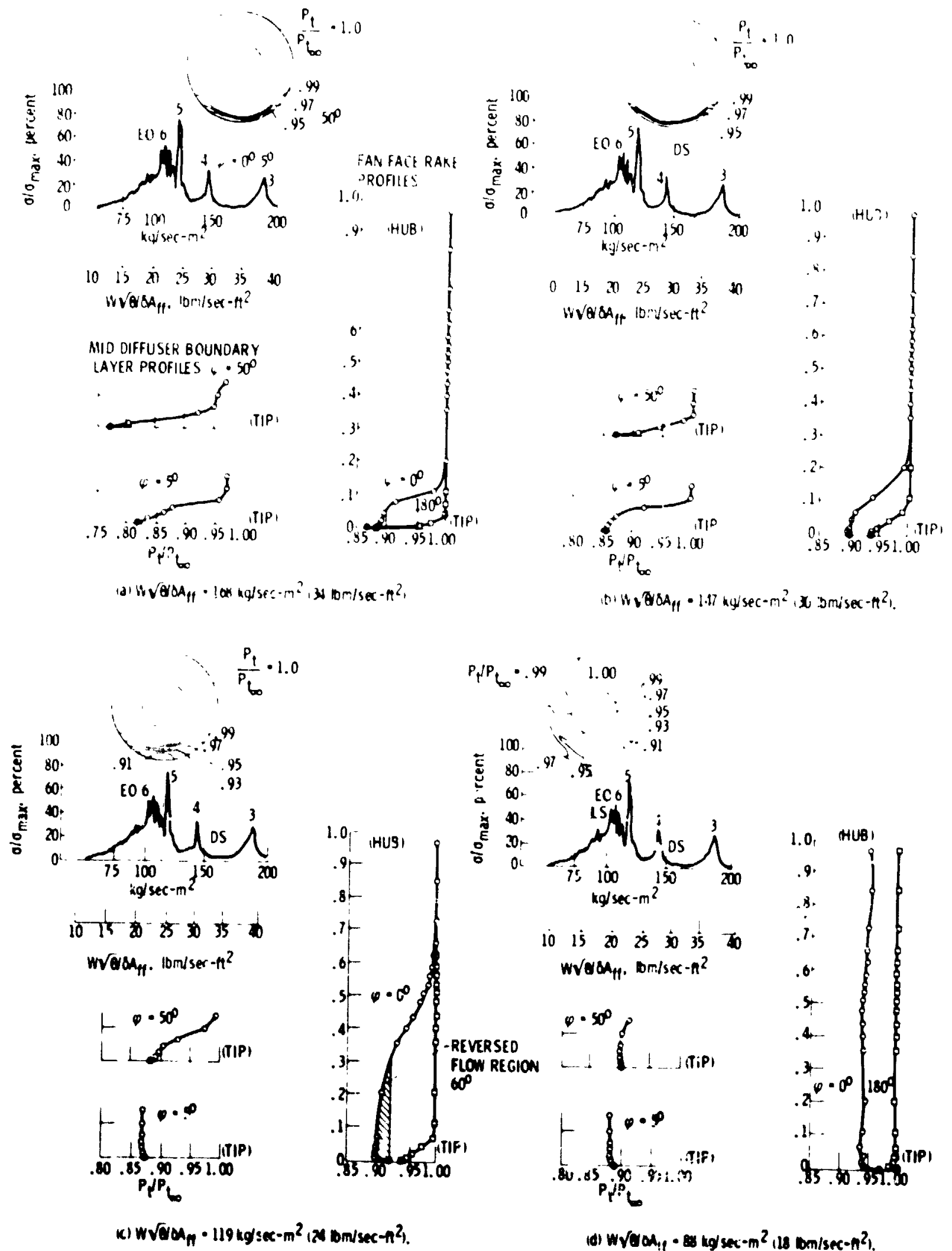

$1.00 \quad: .97$

.95

97.95

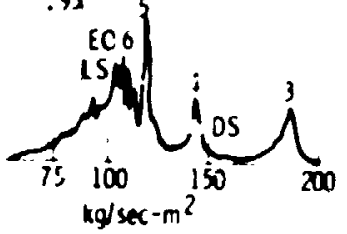

$10 \quad 15 \quad \dot{x} \quad \dot{x} \quad \dot{30} \quad 35 \quad 70$ $w$ veanty. onisec $-n^{2}$

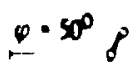
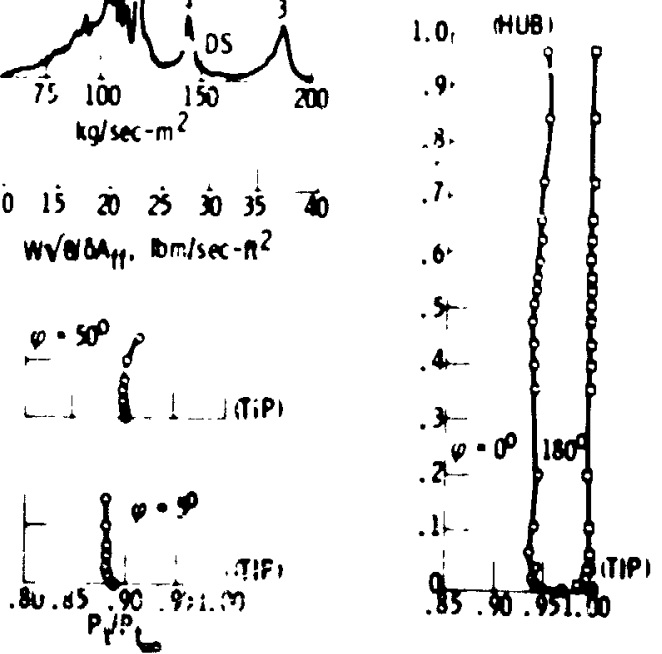

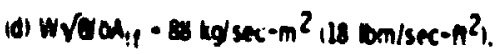

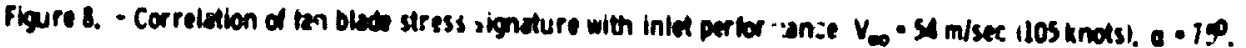




$\begin{array}{cc}\begin{array}{c}W \sqrt{\theta} / \delta A_{\mathrm{ff}}, \\ \mathrm{kg} / \mathrm{sec}-\mathrm{m}^{2}\left(\mathrm{bm} / \mathrm{sec}-\mathrm{ft}^{2}\right)\end{array} & \begin{array}{c}\text { WINOWARD BOUNDARY } \\ \text { LAYER AT FAN FACE }\end{array} \\ 168(34) & \text { ATTACHED } \\ 147(30) & \text { SEPARATED } \\ 119(24) & \text { SEPARATED } \\ 88(18) & \text { SEPARATED }\end{array}$

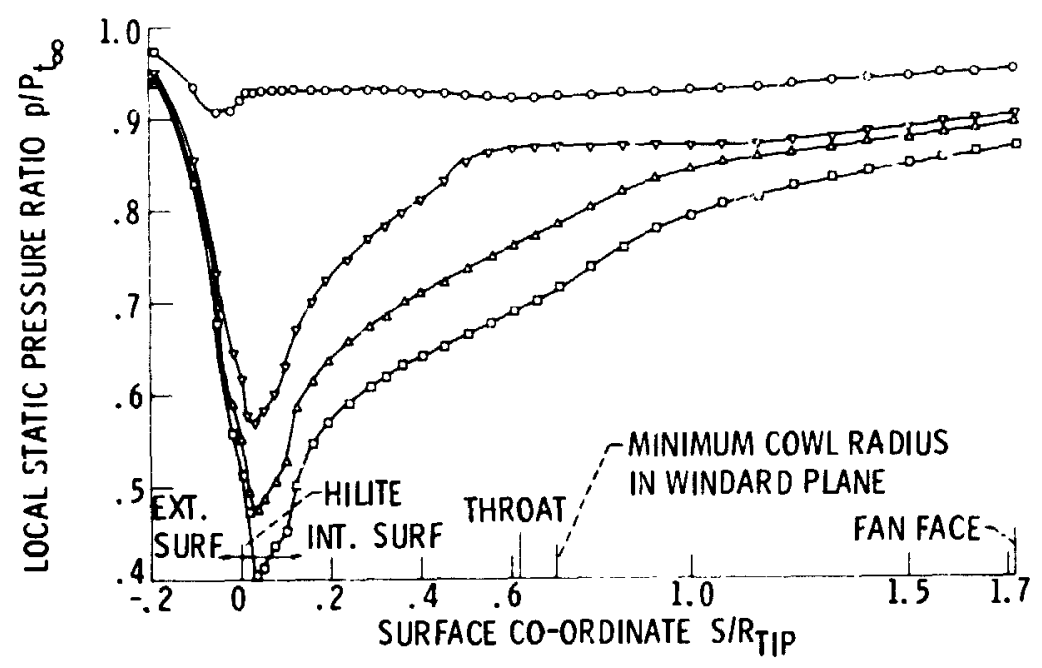

Figure 9. - Tilt nacelle inlet winjward surface static pressure profiles for $v_{\infty}=54$ I sec $\left(105\right.$ knots), $a=75^{\circ}$.
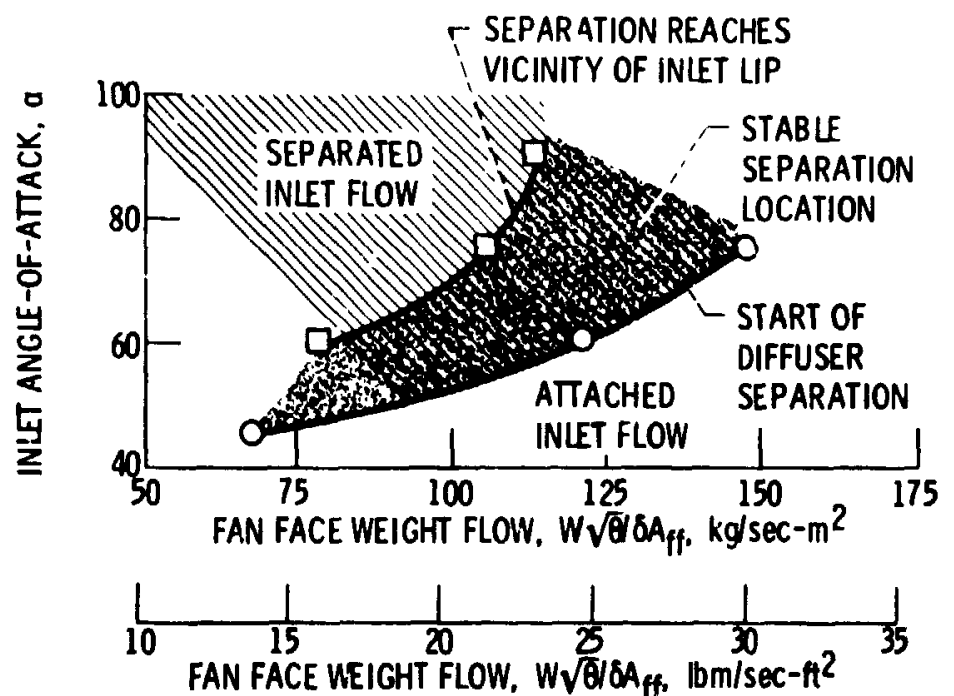

Figure 10. - Tilt nacelle inlet separation boundaries for $V_{\infty}=54 \mathrm{~m} / \mathrm{sec}$ (105 knots). 


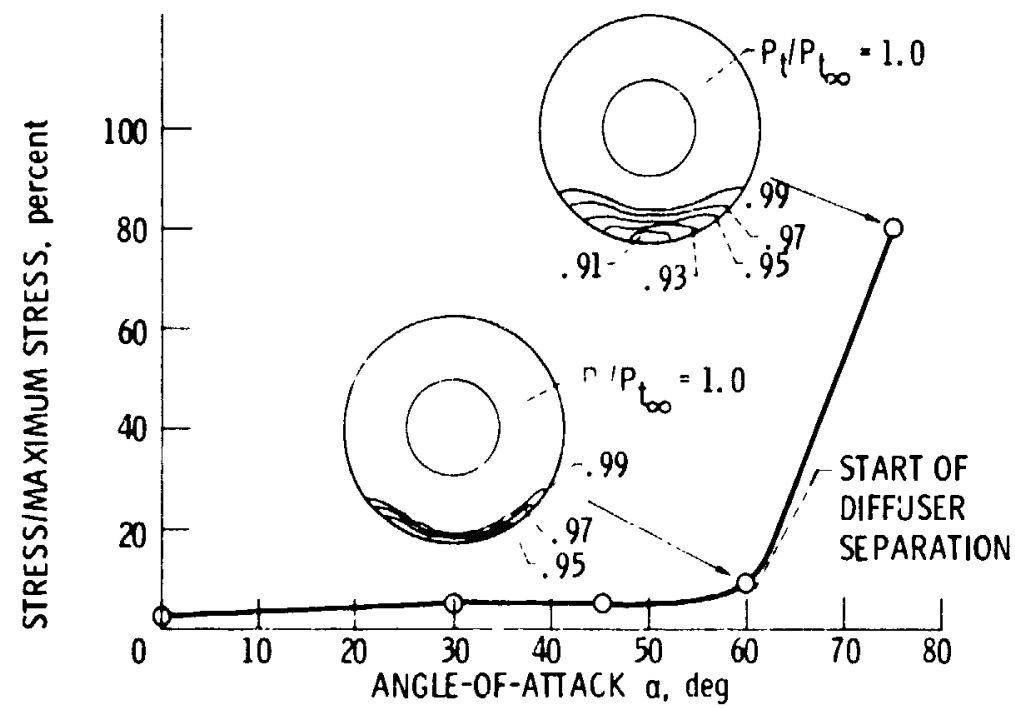

Figure 11. - Variation of EO5 stress level with angle-ofattack, $V_{\infty}=54 \mathrm{~m} / \mathrm{sec}(105$ knots $)$.

DESIRED OPERATING GOALS

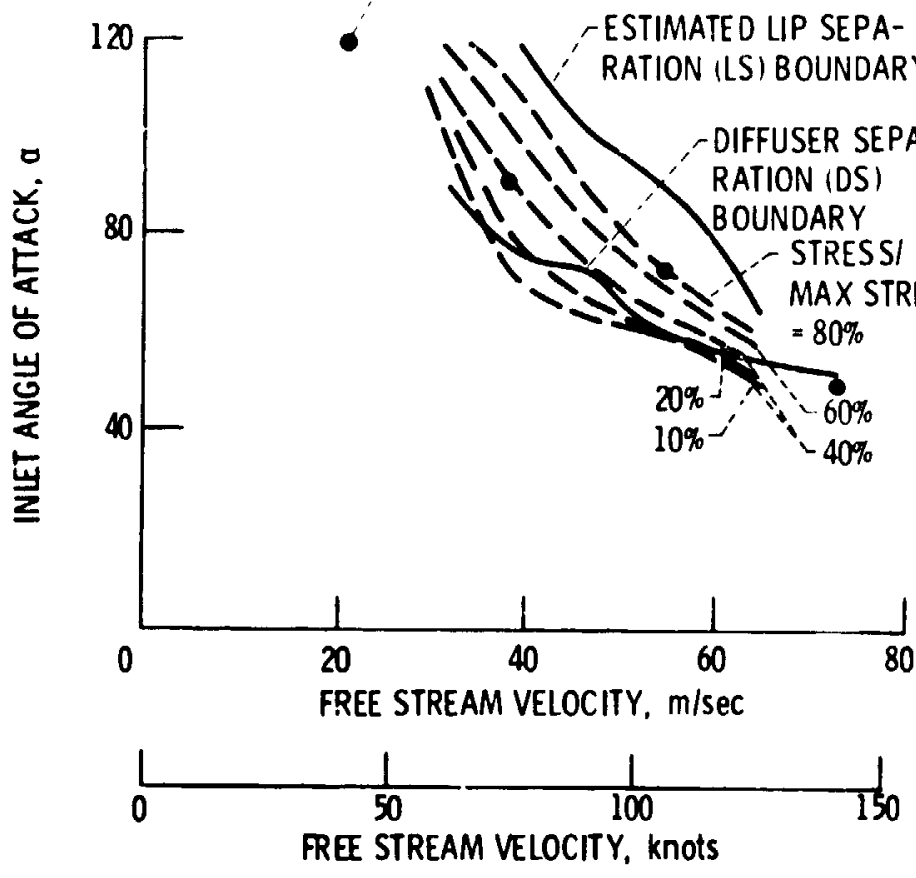

Figure 12. - Comparison of tilt nacelle inlet low speto design goals with expected engine order five (EO5) stress levels. 